\title{
INSIDER TRADING IN INDIA - RULES TILL NOW
}

\author{
Reema Bali ${ }^{*}$ 凶 iD \\ ${ }^{* 1}$ Assistant Professor \& Associate Director Programs (BBA)- RICS School of Built Environment, \\ Amity University, India
}

DOI: https://doi.org/10.29121/granthaalayah.v8.i9.2020.1072

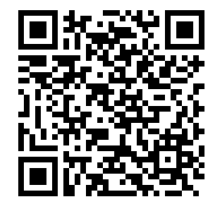

Article Type: Research Article

Article Citation: Reema Bali. (2020). INSIDER TRADING IN INDIA - RULES TILL NOW. International Journal of Research -

GRANTHAALAYAH, 8(9), 49-53. https://doi.org/10.29121/granthaa layah.v8.i9.2020.1072

Received Date: 10 August 2020

Accepted Date: 25 September 2020

Keywords:

Insider Trading

Corporate Fraud

Company Law

\section{ABSTRACT}

This paper analyses the lose threads amongst the SEBI ("Securities and Exchange Board of India") as a regulatory authority ("regulator") who are required enforce the laws and reforms to efface insider trading in the Indian economy. The paper focuses on the role of regulatory authority dealing with the cases of insider trading and the elements that might lead to delay in the resolving the matters which leads to piling up of unresolved matters in insider trading leading to disturbing the economy and loss of faith of investors on the trading activities of stock market.

\section{INTRODUCTION}

Trading of the shares of any company based on the information made available unlawfully to a certain group of people is known as Insider Trading. Section 12-A of the Securities and Exchange Board of India (Amendment) Act, 1992, explicitly prohibits insider trading in securities of companies listed in stock exchanges by stating that "no person shall directly or indirectly deal in securities while in possession of material or non-public information or communicate such material or non-public information to any other person, in a manner which is in contravention of the provisions of this Act or the Rules or the Regulations made there under". Violation of Section 12-A attracts civil penalty under Section 15-G of the Act upto twenty-five crore or three times the amount of profits made out of insider trading, whichever is higher ${ }^{1}$. Insider trading is also a punishable criminal offence under Section 24 of the Act with imprisonment for a term which may extend to ten years, or with fine, which may extend to twenty-five crore rupees or with both.

With the augmentation in financial crimes due to expansion of financial market there is essential need for proper policy formulation and action to be taken by the regulatory authority in order to curb the scandalous transactions arising out of insider trading.

${ }^{1}$ Chapter VA inserted by SEBI (Amendment) Act, 2002 w.e.f. 29th October, 2002

(C) 2020 The Author(s). This is an open access article distributed under the terms of the Creative Commons Attribution License, which permits unrestricted use, distribution, and reproduction in any medium, provided the original author and source are credited. 
Insider Trading in India - Rules till Now

\section{METHODS}

This paper is conceptual in nature and reviews the literature related to the factors which hinders the way to cut out the cases of Insider Trading in India. The paper consists of Secondary data from varied sources to arrive at inferences and conclusions.

\section{DISCUSSION}

\subsection{HISTORICAL BACKGROUND}

In 1940's India first time encountered with insider trading. The Thomas Committee Report in 1948 under the chairmanship of P.J. Thomas, cited instances of directors, agents, officers, auditors possessing strategic information regarding economic conditions of the company regarding the size of the dividends to be declared, or of the issue of bonus shares or the awaiting conclusion of a favorable contract prior to public disclosure ${ }^{2}$.

In 1952, Bhabha committee also recommended to put obligation on the directors to disclose their sale/purchase of shares in a separate register to be maintained by the company.

After observing the recommendations made by the committee, Sections 307 and 308 were incorporated in the Companies Act of 1956. Where Section 307 provided for maintenance of a register by the companies to record the directors' shareholdings in the company and Section 308 prescribed the duty of the directors and persons deemed to be the directors to make disclosure of their shareholdings in the company, subsequently Manager of the company were also included in such section to make the requisite disclosure as per Companies Amendment Act, 1960.

In 1978, the Sacher Committee also pointed out in its report that more stringent laws shall be made to gain information about the transactions where one party gained undue advantage of the transaction who could possibly be in possession of price sensitive information.

The Patel Committee in 1986, headed by G. S. Patel gave a suitable definition of Insider Trading in their report providing that management of the company who are dealing in shares of such company on basis of undisclosed price sensitive information not available to others. It was also recommended to amend the Securities Contract (Regulation) Act ("SCRA"), 1956 in order to allow the exchanges to make stringent policies to curb insider trading.

Further in 1989 Abid Hussain Committee recommended to cover the offence of Insider Trading under civil and criminal laws and also suggested for stricter regulation by SEBI to restrain the unfair practice of Insider Trading.

In the view of requirement to establish proper and stringent laws to deal with the offenders of unfair practice in financial market and with the practical recommendations as provided by various committees, SEBI (Insider Trading) Regulations, 1992 were formed which were subsequently amended in 2002.

\subsection{NEED TO STUDY THE ISSUE}

Insider trading is a malpractice where trading of securities is done by people who have access to the information not otherwise available publically. India is a country where the regulatory bodies despite of setting up of the various statutory reforms are not fully capable of eradicating the unfair practices of insider trading in the financial market.

"The offenders are increasingly getting smart and leaving no trail in the conventional channels," said a regulatory official ${ }^{3}$. Hence the regulator is forced to explore new methods to bring them to book.

Insider trading starts from obtaining Unpublished Price Sensitive Information ("UPSI"), further sharing the same with a certain group of people in order to obtain undue advantage of such information which in its absence

2 Thomas, P.J. (1948). Report on the Regulation of the Stock Exchanges in India. Securities and Exchange Board of India. Retrieved from http://www.mca.gov.in/MinistryV2/library.html. Para 63. Page 68.

${ }^{3}$ Burugula, P. \& Manikandan, A., (2020, January 01). SEBI keeping tabs on social media for insider trading clues, The Economic Times, Retrieved from

http://economictimes.indiatimes.comhttps://economictimes.indiatimes.com/markets/stocks/news/sebi-keeping-tabs-onsocial-media-for-insider-trading-

clues/printarticle/73053225.cms?utm_source=contentofinterest\&utm_medium=text\&utm_campaign=cppst

International Journal of Research -GRANTHAALAYAH 
would not have been possible. Now with the increase in liberty and knowledge provided to investor to deal in financial markets, the instances of infringement of the laws are also increasing rapidly. As per the annual reports of SEBI the number of cases related to insider trading whose investigation was taken during the previous financial year 18-19 was 70 as compared to the number of cases taken up during financial year 17-18 was only 15 . Also the investigation was completed for only 6 cases during the financial year 17-18, whereas investigation for 19 cases were solved during the previous financial year 18-19.

This clearly indicates that where the offenders are trying to find loopholes in the reforms as established by the authorities and gaining undue advantage from such, SEBI has also attempted to deal with such matter in ways possible by forming the requisite laws and regulations to punish the offenders.

The regulations for insider trading have also been ameliorated throughout the years. The erstwhile SEBI (Prohibition of Insider Trading) Regulations, 1992, were replaced with SEBI (Prohibition of Insider Trading) Regulations, 2015 which came into effect from April 01, 2019. The regulations were then amended December 31, 2018 where SEBI addressed the issues related to:

1) Disclosure of certain employees and other connected persons who were earlier not required to make disclosures of having access to "UPSI" under the Regulations, were covered by such amendments.

2) The term "legitimate purposes," was given clarity to avoid evasion of the regulations.

3) Certain drafting ambiguities which created uncertainty among market participants with respect to certain provisions were also clarified.

Further, recent amended in the Regulations were made effective from December 26, 2019, which provides different assistance to the authorities to deal with insider trading, which includes monetary rewards to the informant in order to robust the framework for obtaining information about the tipper, also prevents victimization against employee by an employer acting as informant to the department.

After all such efforts, many big companies and firms were involved in insider trading including Ambit capital who had paid Rs. 6 Crores as per the Settlement agreement of SEBI on December 13, 2019. Similarly, in October 2019 in the matter of Crisil Ltd where proceedings where settled by levying the penalty of Rs. 2 crore by the tipee as per the order passed by SEBI.

Insider trading vigorous efforts to detect and punish in any jurisdiction as it is, therefore merely notifying/ introduction of the laws/regulations is not a solution to any problem. The bigger challenge is implementing the laws in order to benefit the public at large and avoid any mischieves. The main reason in tackling the problem of insider trading is distribution of non-public information through varied sources including social media websites where it is very difficult to establish the relation between the parties to any transaction which lead to the insider trading and gaining undue advantage of such information causing loss to the general public.

Another fact that SEBI has not been empowered with some basic investigative powers and tools is a major reason behind the low prosecution. Lack of proper organisational structure dealing with the cases related to insider trading also adds as a challenge for the regulator. Even today, SEBI does not have the power to tap phone records, a recommendation of the Vishwanathan panel, constituted in August 2017.

A recent case which throws light upon the issue that despite all the efforts made by the regulator, the problem of insider trading still remains in the Indian market. "Recently a Billionaire investor Mr. Rakesh Jhunjhunwala often referred to as India's Warren Buffett has been alleged for insider trading in the shares of Aptech Limited, owned by him and his family. The markets regulator is also investigating other family members who are shareholders, along with Aptech's board members, including Ramesh Damani and Madhu Jayakumar, Jhunjhunwala currently holds 24.24 percent stake in Aptech, which is valued around Rs. 160 crores. It is interesting to take note of a fact that this is not the first time that Aptech limited is under SEBI lens, as SEBI is already investigating Aptech Limited in matter of money routed through GDR which is also in last lap of investigation 4 .

Also, Mr. Jhunjhunwala had earlier been trapped by SEBI for insider trading in Geometric, which is now a part of HCL Technologies, where the case was settled through consent by paying Rs 2.48 lakh by Mr. Jhunjhunwala.

${ }^{4}$ Rakesh Jhunjhunwala under SEBI scanner over insider trading in Aptech. (2020, January 28). Moneycontrol News. Retrieved from https://www.moneycontrol.com/news/business/rakesh-jhunjhunwala-under-sebi-scanner-over-insider-trading-inaptech-report-4865551.html 


\subsection{WAYS TO BRIDGE THE GAP FOR BETTER REDRESSAL OF THE ISSUE}

The identification of problem will go in vain unless supplied with an understanding of suggestions for way ahead. In order to check the difficulties posed by insider trading in India, SEBI needs to consider these suggestions:

1) The Securities and Exchange Board of India (SEBI) needs to increase the level of its organisational structure in terms of level of trained staff to establish proper vigilance mechanism, which will lead to easy identification of chain of networks and interrelations amongst the individual in possession of "UPSI" and who ultimately benefited from such information.

2) SEBI regulations are yet not clear about the very nature of the offence related to insider trading, that whether it shall be dealt as a Civil or criminal offence, which generates puzzlement while deciding the punishments for the defaulters.

3) SEBI along with the manual assistance being provided to as per the laws also requires endowment of supplementary powers to locate the convict such as access to electronic records including wiretapping, emails, etc., which can be salutary step for the SEBI, in dealing with the matters related to insider trading.

4) Educating is the essence of breaking the cycle of improper practice in the society. Therefore, educating the common people and spreading awareness about practice of insider trading and its ill effects will help to build a barrier between the law enforcement and offenders.

5) The transaction held by the individual after obtaining UPSI shall be rescinded and be reversed.

\section{CONCLUSION}

Insider trading is ingrained in Indian Markets and despite the fact that SEBI has been successful in clenching the offenders to some extent who took undue advantage of the Unpublished Price Sensitive Information (UPSI) available to them. Despite the introduction of updated laws/ regulations and efforts to uphold the investigation process, the regulatory authorities are deprived of innumerable facilities to repress the issue of insider trading in the financial market, one of the leading factors is lack of concrete evidence which imposes difficulty to charge the accused with liabilities for Insider trading. Also, it is evident that with the proper policy formulation and increased concentration on the structural formation of the authority, the regulator will be able to widen the quality of evidence and investigative processes and will be able to break the pattern of defiance and secure the balance in the financial market allowing fair distribution of the opportunities amongst varied group of people.

\section{SOURCES OF FUNDING}

This research received no specific grant from any funding agency in the public, commercial, or not-for-profit sectors.

\section{CONFLICT OF INTEREST}

The author have declared that no competing interests exist.

\section{ACKNOWLEDGMENT}

None.

\section{REFERENCES}

[1] Bhabha Committee Report. (1952). Report of Company Law Committee. Retrieved from http://reports.mca.gov.in/Reports/22

Bhabha\%20committee\%20report\%20on\%20Company\%20law\%20committee,\%201952. Page74.

[2] Burugula, P. \& Manikandan, A., (2020, January 01). SEBI Keeping Tabs on Social Media For Insider Trading Clues, The Economic Times, Retrieved http://economictimes.indiatimes.comhttps://economictimes.indiatimes.com/markets/stocks/news/sebi- 
keeping-tabs-on-social-media-for-insider-trading-

clues/printarticle/73053225.cms?utm_source=contentofinterest\&utm_medium=text\&utm_campaign=cppst

[3] Chapter VA inserted by SEBI (Amendment) Act (2002)

[4] Das, S. \& Sahu S. (2015). The Know-All of Insider Trading - Decades of Corruptive Prevention. Retrieved from https://www.lawctopus.com/academike/know-insider-trading-decades-corruptive-prevention/.

[5] Jayshree P. (2020, January 28). Rakesh Jhunjhunwala summoned by SEBI over Aptech insider trades. Livemint. Retrieved from https://www.livemint.com/market/stock-market-news/how-india-cracks-downon-insider-trading-11580199120367.html

[6] Rakesh Jhunjhunwala under SEBI scanner over insider trading in Aptech. (2020, January 282020 ). Moneycontrol News. Retrieved from https://www.moneycontrol.com/news/business/rakeshjhunjhunwala-under-sebi-scanner-over-insider-trading-in-aptech-report-4865551.html

[7] Sachar, R. \& Dr. M. Afzal Wani, (2017, January). Regulation of Insider Trading in India: Dissecting The Difficulties and Solutions Ahead. Journal on Contemporary Issues of Law (JCIL) Vol. 2 Issue 11.

[8] Sacher, R. (1978). Report or the High-Powered Expert Committee on Companies Act and MRTP Act. Ministry of Law, Justice and Company Affair. Retrieved from http://reports.mca.gov.in/Reports/30Rajindar\%20Sacher\%20committee $\% 20$ report\%20of\%20the\%20Highpowered\%20expert\%20committee\%20on\%20Companies\%20\&\%20MRTP\%20Acts,\%201978. Para 8.23.

[9] SEBI Act (1992)

[10] SEBI Annual Report 18-19. (2019). page 190.

[11] Securities and Exchange Board of India (Prohibition of Insider Trading) Regulations, (2015)

[12] Securities and Exchange Board of India. (2019, August 30) Adjudication order no. (ADJUDICATION ORDER NO. AO/SBM/EAD-1/12/2019). page 28.

[13] Thomas, P.J. (1948). Report on the Regulation of the Stock Exchanges in India. Securities and Exchange Board of India. Retrieved from http://www.mca.gov.in/MinistryV2/library.html. Para 63. Page 68.

[14] Zachariah, R. (2020, January 28). Rakesh Jhunjhunwala under SEBI lens for ‘Insider Trading. Economic Times. Retrieved from https://economictimes.indiatimes.com/markets/stocks/news/rakesh-jhunjhunwala-undersebi-lens-for-insider-trading/articleshow/73682542.cms 